\title{
The impact of tree root systems on wastewater pipes
}

\section{Obradović, Dino}

Source / Izvornik: Zajednički temelji '17 : zbornik radova, 2017, 65 - 71

Conference paper / Rad u zborniku

Publication status / Verzija rada: Published version / Objavljena verzija rada (izdavačev PDF)

https://doi.org/10.5592/CO/ZT.2017.03

Permanent link / Trajna poveznica: https://urn.nsk.hr/urn:nbn:hr:133:203477

Rights / Prava: In copyright/Zaštićeno autorskim pravom.

Download date / Datum preuzimanja: 2023-04-26



Repository / Repozitorij:

Repository GrAFOS - Repository of Faculty of Civil Engineering and Architecture Osijek
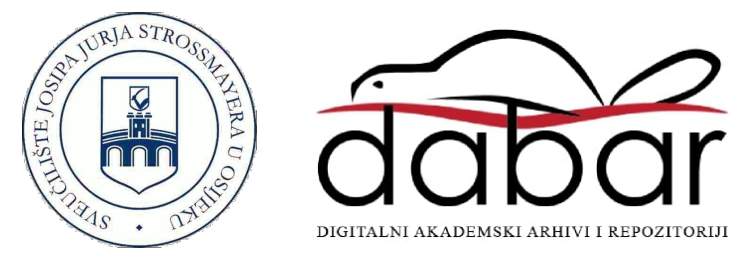


\title{
The impact of tree root systems on wastewater pipes
}

\section{Dino Obradović}

Josip Juraj Strossmayer University of Osijek, Faculty of Civil Engineering

kontakt:dobradovic@gfos.hr

\section{Sažetak}

Kanalizacijski sustav, uz sustav opskrbe pitkom vodom, je najvažniji dio imovine sustava javnog zdravstva nekog grada. Kada je pravilno održavan, kanalizacijski sustav odvodi otpadnu vodu iz kuća i zgrada prema uređaju za pročišćavanje te štiti zdravlje čovjeka. Također, drveće igra važnu ulogu u gradu budući da grad čini atraktivnim, zdravim i održivim. Drveće ima velikih prednosti poput poboljšanja kvalitete zraka, smanjenja oborinskog otjecanja te smanjenja radijacije topline s ulice. Međutim, korijenje drveća, ukoliko prodre u cijev, može prouzročiti začepljenja kanalizacijskih cijevi, pogotovo ako je posađeno na pogrešnom mjestu. Za početak, u radu će se prikazati šteta koju korijenje drveća može prouzročiti. Korijenje može potpuno blokirati ili smanjiti protok, prouzročiti izlijevanje sadržaja kanalizacije ili oštetiti cijevi. Rad će prikazati neke od kemijskih i nekemijskih metoda kontrole/sprječavanja rasta korijenja u kanalizacijske cijevi. Također, dat će se preporuke kako izbjeći štete na cijevima prouzročene korijenjem drveća. Na kraju će se navesti vrste drveća koje se mogu saditi u blizini kanalizacijskih cijevi i one koje treba izbjegavati.

Ključne riječi: kanalizacijske cijevi, kontrola, korijenje drveća, šteta, utjecaj

\section{The impact of tree root systems on wastewater pipes}

\begin{abstract}
The sewer system is, second to the drinking water system, the most important part of the public health assets of a city. When it is operating properly, the sewage system is carrying wastewater away from homes and buildings into the wastewater treatment plant and protecting the public health. Also, trees play an essential role in making a city attractive, healthy, and sustainable. Trees provide significant benefits by improving air quality, reducing stormwater runoff, and reducing radiated heat from the streets. However, if tree roots enter into a wastewater pipe they can cause blockages in those pipes, especially if the trees are planted in the wrong place. First of all, this paper will show the damage that can be caused by tree roots. Tree roots can block or reduce flow, cause overflows of sewer content, or damage pipes. This paper will provide several chemical and non-chemical root growing control methods for sewer lines. Also, it will specify some recommendations on how to avoid damage to wastewater pipes caused by roots. Finally, it will provide some recommendations regarding the tree species suitable for planting near wastewater pipes and some trees that should be avoided.
\end{abstract}

Keywords: wastewater pipes, control, tree roots, damage, impact 


\section{Introduction}

Good maintenance of the sewer system is a prerequisite for the rational management of this set of urban infrastructure, for good sanitary conditions in the urban environment and a good protection of the environment. Good maintenance of sewer system is one of the prerequisites for sustainable development and the standard of health of some of the urban environment; therefore it should be given serious attention [1]. Trees play an important role in maintaining the environment and preserving the natural beauty of a city [2]. Through the collective action of leaves and the anchoring and absorbing effects of roots, trees also contribute to soil stabilization, cleaner water and the recharge of groundwater [3]. Urban trees are well recognized as effective tools for mitigating urban runoff, but the specific role of the root system is largely unrecognized. Root systems aid in dispersal of stormwater into the soil by guiding stormwater along root channels, playing a primary role in base flow, aiding in water infiltration, and absorbing water [4]. However, if trees and plants are planted in the wrong place, their roots can find their way into wastewater pipes and cause sewage overflows. Sewage overflows can affect public health and the environment [2].

Urban soils are often disturbed, manipulated or handled in ways that change their properties and attendant characteristics. These modifications often adversely influence growing conditions [5]. Soil disturbance during installation creates pathways for roots to grow from the surface towards the pipe [6]. Roots grow where the resources of life are available [7]. Moisture and warm temperatures surrounding sewer pipes create excellent environments for root growth [8]. If a pipe is cooler than the surrounding soil, moisture will condense around it creating conditions conducive to root growth [9]. Backfill used during sewer construction may provide more favourable soil for root growth than the existing, surrounding undisturbed soils $[8,10]$.

Essentially, these root growth corridors contain favourable sized pores that can hold water and air, similar those found in topsoil. If pipes have been damaged and leak, then root growth will eventually exploit such regions [6]. Tree roots invade sewer lines because the pipes contain three elements necessary for tree growth: water, nutrients and oxygen. The degree of root invasion is dependent upon the condition of the sewer line, the type of tree and the soil conditions that exist in the root zone [11]. The roots of most trees cannot grow or survive if they are constantly submerged so roots are usually not a problem in sewers that are located below a permanent water table [12].

\section{Pipe damage}

Intrusion of roots into sewers is probably the most destructive problem encountered in a wastewater collection system. Root-related sewer problems include: sewer sto- 
ppages and overflows, structural damage caused by growing roots, formation of septic pools behind root masses, reduction in hydraulic capacity and loss of self-scouring velocities, infiltration in areas where pipes are seasonally under a water table, and exfiltration of sewage into soils around cracked or separated joints [8].

Tree roots are opportunistic and grow where conditions are suitable [13]. Tree roots can enter services via leaking joints and blocked pipes, through deteriorated seals, where the joint has failed or been dislodged or through previous damage. It is rare for a tree root to crack into a properly installed and well-maintained pipe [14]. Cracks in pipes often occur over time and the failure of cement joins and rubber seals are quite common [15]. Older pipes have more root intrusions because of age and materials used [16].
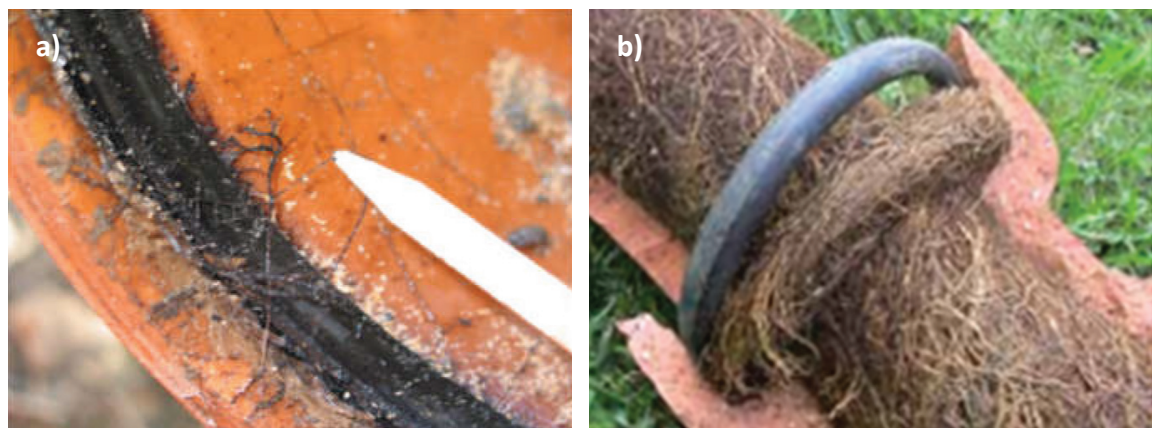

Figure 1. Roots in: a) modern PVC pipe [17]; b) old terracotta pipe - plugged pipe [18]

A pipe is comparatively easy to crack when it is not supported by soil. For the pipe to crack and fail a defect in the pipe needs to be present, or the outer portion of the pipe wall must be compressed. Where roots have a diameter greater than the outside diameter of the pipe, roots may produce sufficient force to dislodge a pipe. In addition, roots that enter through a join between pipes can conceivably develop sufficient surface area to move the pipe a few millimetres until it fully beds in at the next join [15].

\section{Root control methods}

A successful sewer line root control program will integrate a variety of root control methods. This includes non-chemical control methods such as planning and management during sewer line construction, physical control procedures, and mechanical root removal. Chemical control involves the use of certain herbicides [8]. 


\subsection{Non-chemical root control methods}

Although non-chemical methods generally do not provide the same level of results as chemical methods they have an important place in sewer line maintenance [8]. Cultural control of roots in sewers are routine management practices that can prevent roots from invading lines. Cultural controls must be implemented before roots become a problem [12]. Proper planning during sewer line design and construction is a practice that can prevent or minimize tree root invasion problems. Root problems are reduced by: carefully installing and inspecting sewer lines during construction to assure all joints are properly sealed, and controlling the selection of tree species and planting sites near sewer lines $[8,10,12]$.

Physical control of sewer line roots involves isolating the environment of the sewer pipe from roots that could cause problems. Three examples of physical control include tree removal, sewer pipe replacement, and pipe relining $[8,10,12]$.

Mechanical control is the most common method of root control and the most important non-chemical method. Mechanical control involves the use of tools or other devices which cut and remove roots from inside sewers [8, 10, 12]. Some examples of tools and devices for mechanical control are drill machines, rodding machines, jetters and winches. Mechanical control is often used in conjunction with chemical or other controls. For example, mechanical cleaning is used to prepare sewer lines for rehabilitation with pipe lining or regrouting [12].

\subsection{Chemical root control methods}

Root control products, like all chemicals used to kill plants, are herbicides [12]. In this process a root inhibitor chemical is applied to the reticulation sewer pipes considered to have tree roots present. The chemical historically has been applied via a "foaming " process but other processes have been trialled, e.g. spot spraying in conjunction with close circuit television (CCTV) equipment [19].

Many chemicals such as copper sulfate [20], dichlobenil, endothall, metam-sodium, etc. have been used for root control. Also, acid and basic compounds such as sulfamic or sulfuric acid and sodium or potassium hydroxide are commonly used as pour down products in residential settings [8].

Metam-sodium kills the plant roots, while dichlobenil is an effective growth inhibitor. They are applied together as a dry foam. At present, metam-sodium products for sewer usage may only be applied as a foam. The dryer phase of this foam is used to treat smaller pipe (less than $30 \mathrm{~cm}-35 \mathrm{~cm}$ diameter). Wetter foam is used to treat larger pipe (more than $35 \mathrm{~cm}$ diameter). Specially designed foam generating equipment is required to produce and deliver the foam to the interior of the pipe [12]. 


\section{Recommendations to prevent tree root damages}

In landscape design, it is important to select tree species whose roots are less likely to enter sewage and drainage pipes. Correct selection of tree species will result in fewer pipe blockages, fewer tree removals, and less labor for root cutting. Although roots have been accused of causing much damage to pipes, in most instances searching roots entered through a crack. Therefore use PVC pipes because PVC pipes and their joints are more flexible; as a result, they are less likely to crack after soil settling [21]. If faster-growing species are desired, plan to replace trees every 8 to 10 years. When building new sewer lines or improving existing lines, consider landscaping plans and potential root intrusion from trees [11].

Table 1. Recommended trees for planting near sewer pipes [11]

\begin{tabular}{|c|c|c|}
\hline Botanical name & Common name & Common name (in Croatian) [22] \\
\hline Acer ginnala & Amur Maple & Kineski javor \\
\hline Acer palmatum & Japanese Maple & Dlanolisni japanski javor \\
\hline Carpinus betulus & European Hornbeam & Grab \\
\hline Cornus kousa & Kousa Dogwood & Japanski drijen \\
\hline Fagus sylvatica & European Beach & Jorgovan \\
\hline Lagerstroemia spp. & Crapmyrtle & Jabuka \\
\hline Malus spp. & Crabapple & \\
\hline
\end{tabular}

Table 2. Trees not recommended to plant (to avoid) near sewer pipes [2]

\begin{tabular}{|c|c|c|}
\hline Botanical name & Common name & Common name (in Croatian) [22] \\
\hline Acer spp. & Maples (mostly large) & Javor \\
\hline Fraxinus spp. & Ashes (large) & Jasen \\
\hline Pinus spp. & Pine & Platana \\
\hline Platanus spp. & Plane Trees & Marelica, višnja, breskva \\
\hline Prunus spp. & Apricot, cherry, peach \\
\hline Quercus spp. & Oak & Vrba \\
\hline Salix spp. & Willows & \\
\hline
\end{tabular}




\section{Conclusions}

The sewage system is indispensable in every city and it is very important to keep it functioning properly. In order for the sewage system to function properly, it is necessary to perform regular maintenance and take care of the damage and possible leaks in the sewer pipes. Nowadays, with the emphasis on the importance of sustainability, trees are gaining a more important role than they had before, because planting trees has many advantages. By planting trees, we are making the environment of the city more beautiful, reducing the amount of stormwater runoff, reducing surface heating in the city, improving air quality, and more. However, trees can damage sewage pipes with their root systems and it is therefore necessary to pay attention to the location where the trees will be planted and to the species of trees that will be planted. Roots can force their way into pipes to gain access to water and nutrients. In general, when planting trees we should be able to choose the right tree species with a less aggressive root system and make sure that we have planted it far enough from the sewer pipes and thus prevented root penetration into the sewer pipes. Of course, there are also various measures for removing roots from sewer pipes and for preventing their growth in the sewer pipes, however, prevention is highlighted as the most important measure.

\section{References}

[1] Šperac, M., Moser, V., Stvorić, T.: Održavanje kanalizacijskog sustava uz primjenu GIS-a, e-gfos, (2012) 5, pp. 86-94.

[2] Sydney Water: How you can help stop blockages, Tree planting and the wastewater system, http://sydneywaternews.com.au/media/1201/tree-roots-fact-sheet.pdf, pristupljeno: 22.06.2017.

[3] Fazio, J.R.: How Trees can Retain Stormwater Runoff, Tree City USA Bulletin, No. 55, 2012.

[4] Day, D.S., Wiseman, E.P., Dickinson, B.S., Harris, J.R.: Tree Root Ecology in the Urban Environment and Implications for a Sustainable Rhizosphere, Arboriculture \& Urban Forestry, 36 (2010) 5, pp. 193-204.

[5] Randrup, T.B., McPherson, E.G., Costello, L.R.: A review of tree root conflicts with sidewalks, curbs, and roads, Urban Ecosystems, (2001) 5, pp. 209-225.

[6] Pohls, O., Bailey, N.G., May, P.B.: Study of Root Invasion of Sewer Pipes and Potential Ameliorative Techniques, Proceedings International Conference on Urban Horticulture, Eds. R. Junge-Berberovic et al., pp. 113-121, 2004.

[7] Perry, O.T.: Tree Roots: Facts and Fallacies, Arnoldia, 49 (1989), pp. 1-21. 
[8] Marer, J. P.: Sewer Line Root Control, University of California, Statewide Integrated Pest Management Project, Pesticide Education Program, 1996.

[9] Brennan, G., Patch, D., Stevens, F.R.W.: Tree Roots and Underground Pipes, Arboriculture Research Note, Arboricultural Advisory and Information Service, 1997.

[10] Duke, K., Jessen, E.: Sewer Line Chemical Root Control, 1995.

[11] Ward, B., Clatterbuck, W.K.: Choosing Sewer Safer Trees?, https://extension. tennessee. edu/publications/Documents/SP628.pdf, pristupljeno: 22.06.2017.

[12] Eds. Newton, B., Townsend, L.: Sewer root control, Category 16, UK Cooperative extension service, University of Kuntucky-college of agriculture

[13] Sivyer, D.: Roundtable: Sewer lines and trees, City Trees, pp. 24-27, 2006.

[14] City of Sydney: Facts: Trees and their effects on drains and pipes, http://www.cityofsydney.nsw.gov.au/_data/assets/pdf_file/0004/213169/trees_water_sewer_fact_sheet. pdf, pristupljeno: 18.06.2017.

[15] Hartley, M.: Tree Root Damage to Pipes, The Arborist Network, 2012.

[16] Watson, W.G., Hewitt, A.M., Custic, M., Lo, M.: The Management of Tree Root Systems in Urban and Suburban Settings II: A Review of Strategies to Mitigate Human Impacts, Arboriculture \& Urban Forestry, 40 (2014) 5, pp. 249-271.

[17] Stål, O., Östberg, J.: Tree Roots and Sewers, http://www.ikt.de/wp-content/ uploads/2014/10/16-04-stal-tree-roots-and-sewers.pdf, pristupljeno: 22.06.2017.

[18] Western Water, Fact sheet, Tree Roots and sewer pipes: a growing concern, http://www. westernwater.com.au/files/assets/public/documents/fact-sheets-and-brochures/treeroots-and-sewer-pipes-a-growing-concern.pdf, pristup: 19.06.2017.

[19] Thomson, G.: Investigation of sewer blockages due to tree roots, 71st Annual Water Industry Engineers and Operators' Conference, pp. 71-78., 2008.

[20] Mitchell, P.J., Schnelle, M.A.: Controlling Tree Roots in Sewer Lines with Cooper Sulfate, Current report, Oklahoma Cooperative Extension Service, Division of Agricultural Sciences and Natural Resources

[21] Svihra, P.: Ranking of trees according to damage of sewage pipes, Ornamental Northwest Archives, 11 (1987) 4, pp. 7.

[22] Herrmann, W.: Voćnjak, ukrasni grmovi, travnjaci i drveće, Marjan tisak d.o.o., Split, 2007. 